\title{
PENYELESAIAN PERSELISIHAN ADAT ISTIADAT DALAM KEHIDUPAN MASYARAKAT DI KABUPATEN ACEH BARAT BERDASARKAN TINJAUAN PERATURAN GUBERNUR ACEH
}

\author{
Nellis Mardhiah \\ Teuku Umar University \\ Faculty of Social and Political Sciences \\ nellismardhiah@gmail.com
}

The aim of this study was to know the customs and traditions of dispute mechanism in community life of Gampong Baroh Pasi Aceh, Meurebo District, West Aceh. The methodology of the study was intentionally used a phenomenological approach in order to understand social phenomena in the life of the community in resolving the conflict. The subjects were in-depth interviews with village officials and traditional leaders in getting information by assuming the social cases show that the problem is not solved by custom. The research results of Governor Regulation No. 60 Year 2013 on Implementation Grievance /dispute customs and traditions in the Gampong Pasi Aceh Baroh, Meureubo District, West Aceh has not run optimally, it can be seen in the attitude of people who prefer the legal system in solving the problem of settlement through traditional institutions, especially in Gampong Baroh Pasi Aceh, Meureubo District, West Aceh. In addition, the government of Gampong Pasi Aceh Baroh to act as traditional authorities has not yet fully understand and know about the presence of the gubernur of regulation No. 60 Year 2013 on implementation of dispute resolution/dispute customs and ceremonies in Gampong Pasi Aceh Baroh, Meureubo District, West Aceh. In conclusion, the Gampong Pasi Aceh Baroh must fully understand that the traditional dispute resolution have gotten as few as follows: first, custom solution for cheap and filled with elements of familiarity; and second, custom solution for legally binding and recognized by the formal legal institutions based on the rule of governor.

Key Word: Settlement of Disputes, Customs, Government of the village. 


\section{PENDAHULUAN}

Merujuk dalam konstitusi pembukaan Undang-Undang Dasar 1945 dijelaskan bahwa, tujuan didirikan negara Indonesia adalah semata-mata untuk melindungi segenap bangsa Indonesia dan seluruh tumpah darah Indonesia, serta memajukan kesejahteraan umum, mencerdaskan kehidupan bangsa dan ikut melaksanakan ketertiban dunia. Dari penjelasan konstitusi tersebut dapat dimaknai bahwa, sudah menjadi kewajiban dan tanggung jawab negara untuk melindungi warganya serta menyediakan dan mengupayakan sarana-sarana umum dalam berbagai aspek kehidupan berbangsa dan bernegara sebagai perwujudan tujuan dan cita-cita negara yang berlandaskan pada nilainilai pancasila dan Undang-Undang Dasar $1945^{1}$.

Penyelesaian berbagai-bagai perkara di Indonesia adanya lembaga peradilan mempunyai fungsi yang sangat penting dalam mewujudkan ketentraman dan kedamaian warga masyarakat, terutama dalam memenuhi rasa keadilan bagi para pencari keadilan. Salah satu fungsi yang penting adalah menyelesaikan sengketa/perselisihan yang terjadi dalam masyarakat. Sengketa atau perselisihan dapat terjadi setiap saat dalam pergaulan hidup manusia, sesuai dengan kodratnya manusia diciptakan oleh Allah SWT untuk hidup bersama manusia lainnya dengan beragam kepentingan sengketa perselisihan.

Indonesia dikenal berbagai jenis peradilan yang dilaksanakan oleh di bawah naungan Mahkamah Agung dan badan peradilan yang berada di bawahnya dalam lingkungan peradilan umum, lingkungan peradilan agama, lingkungan peradilan militer, lingkungan peradilan tata usaha negara, dan oleh Mahkamah Konstitusi. Keberadaan peradilan tersebut sebagai tempat bagi para pihak yang bersengketa mencari keadilan, baik perkara pidana atau perkara perdata. sebagaimana diatur dalam Pasal 25 UU Kekuasaan Kehakiman. Lembaga peradilan yang akan dibahas lebih lanjut adalah peradilan informal yang ada dalam Masyarakat Aceh iaitu, Peradilan Adat Gampong, yang keberadaannya diakui oleh aturan perundang-undangan di Indonesia.

Berdasarkan ketentuan dalam peraturan Gubernur Nomor 60 Tahun 2013 tersebut menjelaskan bahwa Aceh adalah daerah provinsi yang merupakan kesatuan masyarakat hukum yang bersifat istimewa dan diberi kewenangan khusus untuk mengatur dan mengurus sendiri urusan pemerintahan dan kepentingan masyarakat setempat sesuai dengan peraturan perundang-undangan dalam sistem dan prinsip negara republik Indonesia.

Qanun Nomor 5 Tahun 2003 (Tentang Pemerintahan Gampong) pada pasal 11 disebutkan bahwa Keuchik adalah Badan Eksekutif gampong dalam penyelenggaraan pemerintahan gampong. Dengan sistem pemerintahan gampong yang menganut demokrasi Bottom-up benar-benar dapat dilakukan. Dalam pemerintahan gampong di bidang eksekutif dilaksanakan oleh Keuchik dan Tengku Imum Meunasah dengan urusan yang berbeda. Pimpinan Keagamaan di jabat oleh Tgk Imum Meunasah² .

${ }^{1}$ Djuned, T. M. 2003. Menuju Revitalisasi Hukum dan adat Aceh, Yayasan Rumpun Bambu dan CSSP, Jakarta.

2Sulaiman Tripa, Prospek dan Tantangan Pemerintahan Gampong di Nanggoroe Aceh Darussalam, Jurnal Media Hukum, Vol 16 No 2 Desember 2009. 
Penyelengaraan menurut Peraturan Gubernur Aceh Nomor 25 Tahun 2011 Tentang Pedoman Umum Penyelenggaraan Pemerintahan Gampong Pada Bab III Pasal 4 disebutkan bahwa penyelenggaraan pemerintahan gampong mempunyai asas meliputi pengakuan dan penghormatan, desentralisasi dan tugas pembantuan. Kemudian, di dalam Pasal 5 disebutkan bahwa Pedoman Umum Penyelenggaraan Pemerintahan gampong yang diatur dalam peraturan Gubernur ini meliputi sebagai berikut :

1. Pendahuluan

2. Kewenangan gampong

3. Kelembagaan gampong

4. Pembentukan, penggabungan, dan penghapusan gampong

5. Penyelesaian sengketa menurut hukum adat

6. Perencanaan pembangunan gampong

7. Badan usaha milik gampong

8. Kerja sama gampong

9. Administrasi pemerintahan gampong

10. Penyusunan Qanun gampong

11. Laporan penyelenggaraan pemerintahan gampong

12. Penutup

Propinsi Aceh merupakan salah satu propinsi yang terletak ujung barat sumatera yang merupakan bagian terintegrasi dari negara Indonesia, dengan status pemerintahan otonomi khusus (lex spesialis), sebagaimana diatur dalam Undang-Undang Nomor 11 Tahun 2006 tentang pemerintahan Aceh. Secara regulatif Aceh sebelumnya juga menyandang status ekonomi khusus dengan sebutan Propinsi Nanggro Aceh Darusalam (NAD) yang diatur dalam Undang- Undang Nomor 18 Tahun 2001 (Undang-Undang Nomor 11 Tahun 2006).

Peraturan Gubernur Aceh Nomor 60 Tahun 2013 Tentang Pelaksanaan Penyelesaian Sengketa/Perselisihan Adat dan istiadat serta turunan dari Undang-Undang Nomor 11 Tahun 2006 Tentang Pemerintahan Aceh dan Qanun Aceh Nomor 5 Tahun 2003 Tentang Pemerintahan Gampong yang dijadikan rujukan dan serta pedoman dalam melaksanakan fungsi dan tugas Pemerintahan Gampong di Aceh. Menurut observasi yang dilakukan di Gampong Pasi Aceh Baroh Kecamatan Meureubo Kabupaten Aceh Barat bahwa, penyelesaian sengketa secara adat diluar pengadilan formal sebagaimana yang ditegaskan dalam Peraturan Gubernur Aceh Nomor 60 Tahun 2013 Tentang Pelaksanaan Penyelesaian Sengketa/Perselisihan Adat dan Istiadat belum berjalan secara maksimal, hal tersebut dapat dilihat dari beberapa masyarakat yang lebih memilih penyelesaian hukum secara formal dalam menyelesaikan kes-kes sosial salah satu masalah perselihan paham, pencurian dan batas wilayah tanah. Dimana dalam hal ini adalah kasus secara adat dan istiadat belum berjalan lancar seperti Peraturan gubernur Nomor 60 Tahun 2013 di selesaikan secara adat istiadat Gampong, tetapi diselesaikan secara kepolisian. 


\section{PEMBAHASAN}

A. Peraturan Gubernur Aceh Nomor 25 Tahun 2011 (Tentang Pedoman Umum Penyelenggaraan Pemerintahan Gampong)

Pemerintahan gampong berkedudukan sebagai unsur penyelenggara Pemerintahan Gampong, bersama-sama dengan unsur Tuha Peut gampong, menyelenggarakan urusan pemerintahan gampong. Pemerintahan gampong terdiri atas Keuchik dan Badan Permusyawaratan gampong yang disebut dengan Tuha Peut atau nama lain. Dalam melaksanakan tugas, Keuchik dibantu oleh perangkat gampong yang dibantu oleh Sekretaris gampong dan perangkat gampong lainnya (Peraturan Gubernur Aceh Nomor 25 Tahun 2011). Perangkat Gampong terdiri atas Sekretaris Gampong, Kepala Urusan, dan perangkat lainnya. Sekretaris gampong diisi dari Pegawai Negeri Sipil yang memenuhi persyaratan. Sementara Sekretaris Desa yang sudah ada sebelum pemberlakuan Undang - Undang Nomor 32 Tahun 2004 (Tentang Pemerintahan Daerah) Diisi bukan dari Pegawai Negeri Sipil, namun secara bertahap akan diangkat menjadi Pegawai Negeri Sipil sesuai dengan peraturan perundang-undangan yang berlaku ${ }^{3}$.

Peraturan Gubernur Aceh Nomor 25 Tahun 2011 (Tentang Pedoman Umum Penyelenggaraan Pemerintahan Gampong) Perangkat Gampong berkedudukan sebagai unsur pembantu dan bertanggung jawab kepad Keuchik. Dalam melaksankan tugas Keuchik di bantu oleh perangkat gampong yang terdiri dari sekretariat gampong, pelaksana teknis lapangan dan unsur kewilayahan.

Perangkat gampong sebagaimana yang diatur dalam regulasi yang ada terdiri dari

1. Sekretaris gampong terdiri dari unsur staf, memimpin sekretariat gampong dalam rangka membantu tugas Keuchik dalam melaksanakan tugas dan fungsinya dalam menjalankan pemerintahan gampong.

2. Unsur staf sekretariat gampong, penataan unsur staf sekretariat gampong harus mencerminkan kategori fungsi dalam mengelola administrasi pemerintahan gampong, sehingga nomenklatur yang dapat digunakan adalah "Kepala Urusan", namun dapat pula menggunkan nomenklatur lain sesuai dengan sistem nilai dan adat.

Undang - Undang Nomor 11 Tahun 2006 tentang Pemerintahan Aceh dijelaskan bahwa, pemerintahan desa di Aceh disebut gampong. Gampong adalah kesatuan masyarakat hukum yang mempunyai organisasi pemerintahan terendah langsung berada di bawah mukim atau nama lain yang menempati wilayah tertentu, yang di pimpin oleh Keuchik atau nama lain yang berhak melaksanakan rumah tangganya sendiri. Ada tiga unsur pimpinan gampong yaitu Keuchik, Teungku Meunasah, dan Tuha Peut, akan tetapi dalam menjalankan kekuasaan lebur menjadi satu dan dijalankan oleh Keuchik. Kuala.

${ }^{3}$ Abdullah, Adnan. 1982. Kepemimpinan Pedesaan di Aceh. Banda Aceh: Universitas Syiah 


\section{B. Qanun Nomor 5 Tahun 2003 Tentang Pemerintahan Gampong}

Qanun Nomor 5 Tahun 2003 Tentang Pemerintahan Gampong adalah sebagai penjelasan kedudukan gampong sebagai substantif wilayah autonomi dari bahagian wilayah provinsi. Gampong merupakan gabungan gampong-gampong yang disebut Mukim yang dikepalai oleh Imum Mukim. Mukim adalah kesatuan masyarakat hukum dalam Propinsi Aceh yang terdiri atas gabungan beberapa gampong yang mempunyai batas-batas wilayah tertentu dan harta kekayaan sendiri, berkedudukan langsung di bawah kecamatan, yang dipimpin oleh Imum Mukim. Jabatan yang dipegang secara turuntemurun, karena di Aceh masyarakat pedesaannya kuat dipengaruhi oleh Agama Islam maka peranan Teungku Meunasah di gampong sangat berpengaruh. Biasanya pemerintahan desa tersebut dilaksanakan oleh Imum, Keuchik, dan Teungku Meunasah, bersama-sama dengan Majelis Ureng Tuha. ${ }^{4}$

Gampong dalam arti fisik merupakan sebuah kesatuan wilayah yang meliputi tempat hunian, blang, padang dan hutan. Dalam arti hukum, gampong merupakan Persekutuan Masyarakat Hukum Adat yang bersifat teritorial. Sedangkan Gampong merupakan tempat hunian berbagai Belah yang meliputi wilayah tempat hunian, padang, persawahan dan hutan. Belah di Aceh Tengah merupakan persekutuan masyarakat hukum adat.

Lebih lanjut T. Djuned Dkk (2002:h.12) pemerintahan di tingkat gampong terdiri dari beberapa pejabat, yaitu:

a. Keuchik Gampong (Kepala Desa). Keuchik Gampong berkewajiban :

1) Menjaga ketertiban, keamanan, dan adat istiadat dalam desanya

2) Menjalankan perintah atasan

3) Berusaha memakmurkan desanya

4) Menjalankan tugas sosial kemasyarakatan yang dikemas dalam istilah keureuja udep dan keureuja mate

5) Ikut serta dalam setiap peristiwa hukum seperti transaksi jual beli tanah, perkawinan dan lain-lain

6) Memberi keadilan di dalam perselisihan-perselisihan

b. Teungku Imum Meunasah. Merupakan pimpinan di bidang keagamaan, mulai dari mengaji Al-Qur'an dan menanamkan dasar-dasar ketauhidan, memimpin berbagai upacara keagamaan dan memberi nasehat-nasehat spiritual bagi keuchik gampong apabila diperlukan.

c. Tuha Peut. Merupakan dewan orang tua yang mempunyai pengetahuan yang luas tentang adat dan agama. Tuha Peut ini terdiri dariKeuchik Gampong, Imum Meunasah, dan Kepala Jurong (kepala lorong).

d. Tuha Lapan. Merupakan dewan tertinggi di tingkat gampong yang terdiri dari Tuha Peut, Guree Semebeut (Guru ngaji), para cerdik pandai dan tokoh-tokoh pemuda.

${ }^{4}$ Djuned, T. M. 2003. Menuju Revitalisasi Hukum dan adat Aceh, Yayasan Rumpun Bambu dan CSSP, Jakarta 


\section{Sistem Hukum Adat Pemerintah Gampong}

Sistem hukum adat merupakan suatu bagian dari hukum nasional, artinya tetap diakui dan dihormati di Indonesia. Dalam sistem hukum adat ini salah satunya bersifat komunal, adat merupakan cerminan kepribadian suatu bangsa dan penjelmaan jiwa bangsa yang bersangkutan dari abad ke abad. Hukum adat pertama kali diperkenalkan oleh Cornelis Snouck Hoogronje di Indonesia dari bahasa belanda "adatrech" yang selanjutnya dipakai olehVollenhoven dengan "tehnis juridis".

Dalam bukunya "de atjehers" yang menampilkan istilah adatrecht tahun 1893, Snouck menunjukkan hukum yang mengendalikan kehidupan masyarakat. Aceh adalah adat yang mempunyai konsekuensi hukum dalam teorinya "receptie" yang diberlakukan Belanda menegakkan hukum Islam hanya berlaku bagi orang Indonesia bila telah diterima oleh hukum adat.

Undang-undang Nomor 44 Tahun 1999 (Tentang Keistimewaan Aceh) disebutkan bahwa, Aceh merupakan sebuah daerah di Indonesia yang diberi keistimewaan dalam bidang penyelenggaraan adat istiadat, tentu hal ini juga terintegrasi dengan hukum adat yang berlaku di Aceh, yang sampai dengan saat ini tetap di junjung tinggi dan dihormati oleh masyarakat Aceh dalam menyelesaikan beberapa pesoalan masyarakat. Untuk mengelola dan menjaga adat istiadat di Aceh hingga saat ini pemerintah Aceh membentuk badan non struktural yang bernama dengan Majelis Adat Aceh (MAA).

Penyelesaian sengketa secara adat merupakan salah satu alternatif penyelesaian sengketa yang terjadi dalam masyarakat diluar peradilan formal. Ada peradilan formal seperti Pengadilan Negeri, Mahkamah Syariah dan lainnya. Diluar pengadilan formal kita mengenal berbagai alternatif dalam penyelesaian sengketa, seperti mediasi dan lain sebagainya.

Dalam kehidupan masyarakat yang berbasis kehidupan adat di Aceh kita mengenal adanya mekanisme dalam penyelesaian sengketa secara damai oleh lembaga adat. Penyelesaian oleh lembaga adat inilah yang dimaksud dengan penyelesaian. Penyelesaian sengketa secara adat dilakukan dengan pendekatan musyawarah dan bertujuan damai. Pelaksanaan peradilan harus didasari pada filosofi penyelesaian masalah bukan hanya sekedar memutuskan perkara, tetapi menyelesaikan dan mengakhiri permasalahan.

Mendasari pada filisofi diatas maka tujuan penyelesaian sengketa secara adat dimaksud adalah untuk mengembalikan keseimbangan dalam masyarakat, merukunkan dan mengharmoniskan mereka yang bersengketa. Kerukunan, ketentraman daqn keharmonisan masyarakat menjadi tujuan utama dalam pelaksanaan penyelesaian sengketa secara adat. (Pergub. Aceh Nomor 25 Tahun 2011).

\section{Prinsip-prinsip dalam Penyelesaian Sengketa Secara Adat}

Penyelesaian sengketa secara adat adalah peradilan perdamaian yang dimaksudkan adalah peradilan perdamaian untuk menyelesaikan perkara (sengketa atau pelanggaran adat yang ada) yang terjadi didalam masyarakat yang ditunjukkan adalah menciptakan kedamaian dan keharmonisan hidup masyarakat, bukan untuk memutuskan kalah atau menang. Disinilah letak filosofi penyelesaian secara adat dan dengan peradilan formal 
negara. Untuk itu penyelesaian sengketa secara adat harus disadari pada prinsip-prinsip dasar guna terselenggaranya peradilan yang bisa diterima oleh pihak dan bisa mewujudkan kedamaian dan kerukunan hidup masyarakat yang bersangkutan. Prinsip dasar yang harus dipedomani dalam penyelesaian secara adat adalah sebagai berikut:

1. Terpercaya atau amanah. Peradilan adat didasari pada kepercayaan masyarakat itu fungsionarisnya adalah tokoh adat yang dapat dipercaya.

2. Tanggung jawab. Penyelesaian sengketa secara adat didasari pada tanggung jawab pelaksanaannya kepada para pihak masyarakat dan Allah SWT.

3. Seteraan didepan hukum. Dalam penyelesaian sengketa tidak boleh dibeda bedakan, jenis kelamin, status sosial, umur. Semua orang mempunyai kedudukan yang sama didepan adat.

4. Cepat Murah dan Mudah. Proses peradilan dilaksanakan secara cepat, tidak boleh dilarut-larutkan dan mudah. Putusannya harus terjangkau untuk dilaksanakan oleh masyarakat.

5. Ikhlas dan suka rela. Tidak boleh memaksa para pihak untuk menyelesaikan perkaranya melalui penyelesaian sengketa secara adat.

6. Penyelesaian secara damai. Dalam penyelesaian sengketa berprinsip dalam bahasa Aceh di kenal dengan ungkapan "Uleue beu matee ranteng bek patah". Penyelesaian sengketa secara adat ini harus benar-benar menyelesaikan masalah, guna mengembalikan keseimbangan dan kerukunan hidup masyarakat.

7. Musyawarah atau mufakat. Keputusan yang dibuat dalam penyelesaian sengketa secara adat didasari pada hasil musyawarah dan mufakat yang berlandaskan pada hukum adat.

8. Keterbukaan untuk umum. Semua proses peradilan, (kecuali dalam kasus-kasus tertentu, seperti perkara keluarga) dijalankan dengan cara yang terbuka.

9. Jujur. Pelaksanaan sengketa secara adat dilaksanakan secara jujur. Setiap pemimpin adat tidak boleh mengambil keuntungan dalam bentuk apapun, baik materil maupun non materi dalam penanganan perkara.

10. Keberagaman. Penyelesaian sengketa secara adat menghargai keberagaman ketentuan adat dalm berbagai subsistem hukum adat yang berlaku dalam masyarakat.

11. Praduga tak bersalah. Hukum adat tidak dibenarkan maain hakim sendiri dalam proses peradilan, para pihak tidak dianggap bersalah sampai adanya putusan.

12. Berkeadilan. Putusan penyelesaian sengketa secara adat harus bersifat adil dan keputusannya diterapkan sesuai dengan kualitas perkara dan tingkat ekonomi para pihak.

Prinsip-prinsip dasar tersebut harus benar-benar diperhatikan dalam pelaksanaan penyelesaian sengketa secara adat, karena implementasi prinsip tersebut berkaitan dengan persoalan-persoalan perlindungan hak asazi manusia. Tidak boleh melanggar hak asasi manusia apapun alasannya, jangan sampai inginmenegakkan hukum adat akan melanggar hak asasi hukum adat orang lain. Mendasari hak asasi manusia dalam hukum adat maka dalam penyelesaian sengketa secara adat, maka jadi pertimbangan sebagai berikut: 
a. Tidak boleh ada pemaksaan kepada siapapun agar bersedia menyelesaikan permasalahan sengketa secara adat. Apabila para pihak tidak bersedia maka permasalahannya diserahkan saja pada peradilan formal.

b. Tidak boleh membeda-bedakan orang, karena status sosial, penduduk asli dan pendatang atau sebagainya semua harus diperlakukan sama.

c. Tidak boleh memberikan sangsi adat sebelum seseorang benar-benar terbukti melakukan kesalahan.

d. Tidak boleh menerapkan hukum adat yang memihak sehingga dirasakan tidak adil.

Penyelesaian sengketa secara adat merupakan wadah penyelesaian sengketa yang diperankan oleh beberapa tokoh adat baik yang ada di tingkat gampong maupun di tingkat mukim. Tokoh adat yang terlibt dalam penyelesaian sengketa inilah yang dimaksud sebagai fungsionaris penyelesaian sengketa secara adat. Tidak semua petua adat terlibat sebagai fungsionaris adat (fungsionaris penyelesaian sengketa secara adat) dalam penyelesaian sengketa dalam masyarakat. Sekarang ini dikenal dua fungsionaris penyelesaian sengketa secara adat, yakni fungsionaris pada tingkat gampong dan fungsionaris pada tingkat mukim.

Fungsionaris adat penyelesaian sengketa secara adat pada tingkat gampong adalah Keuchik, Imum Meunasah, dan Tuha Peut gampong, ditambah dengan salah satu petua adat (petua lembaga adat) menurut kasusnya dan dibantu oleh sekretaris gampong sebagai juru tulis (panitera).

Fungsionaris yang menjadi majelis penyelesaian sengketa secara adat, yaitu :

1. Keuchik tahu nama lain

2. Imum meunasah atau nama lain

3. Tuha peut atau nama lain

4. Sekretaris gampong atau nama lain

5. Ulama, cendikiawan, dan tokoh adat lainnya di gampong atau nama lain yang bersangkutan, sesuai dengan kebutuhan.

Peraturan Gubernur Nomor 60 Tahun 2013 Tentang Pelaksanaan Penyelesaian Sengketa/Perselisihan Adat Dan Istiadat. Adat istiadat adalah tata kelakuan yang kekal dan turu temurun dari generasi pendahulu yang dihormati dan di muliakan sebagai warisan yang bersendikan syariat islam. Adat adalah aturan perbuatan dan kebiasaan yang telah berlaku dalam masyarakat yang dijadikan pedoman dalam pergaulan hidup di Aceh.

Maksud dan tujuan Pergub ini adalah terpenuhinya keadilan bagi semua pihak terutama pihak-pihak yang bersengketa atau berkonflik dan tidak ada satupun yang merasa di rugikan.Salah satu penyelesaian sengketa yang di bahas pada Pergub ini adalah penganiyaan ringanPenganiyaan ringan yang dimaksud dalam Pergub ini adalah penganiyaan yang tidak menimbulkan pendarahan berat dan/atau tidak menimbulkan cacat fisik dan/atau psikis.Penyelesaian sengketa secara adat di gampong dilaksanakan oleh tokoh-tokoh adat yang terdiri dari:

a. Keuchik atau nama lain 
b. Imeum Meunasah atau nama lain

c. Tuha Peut atau nama lain

d. Sekretaris gampong atau nama lain

e. Ulama, cendikiawan dan tokoh adat lainnya di gampong atau nma lain.

Penyelesaian sengketa secara adat merupakan salah satu alternatif penyelesaian sengketa yang terjadi dalam masyarakat diluar peradilan formal. Ada peradilan formal seperti Pengadilan Negeri, Mahkamah Syariah dan lainnya. Diluar pengadilan formal kita mengenal berbagai alternatif dalam penyelesaian sengketa, seperti mediasi dan lain sebagainya. Dalam kehidupan masyarakat yang berbasis kehidupan adat di Aceh kita mengenal adanya mekanisme dalam penyelesaian sengketa secara damai oleh lembaga adat. Penyelesaian oleh lembaga adat inilah yang dimaksud dengan penyelesaian. Penyelesaian sengketa secara adat dilakukan dengan pendekatan musyawarah dan bertujuan damai. Pelaksana peradilan harus didasari pada filosofi penyelesaian masalah bukan hanya sekedar memutuskan perkara, tetapi menyelesaikan dan mengakhiri permasalahan.

Mendasari pada filosofi dia atas maka tujuan penyelesaian sengketa secara adat dimaksudkan adalah untuk mengembalikan keseimbangan dalam masyarakat, merukunkan dan mengharmoniskan mereka yang bersengketa. Kerukunan, ketentraman dan keharmonisan masyarakat menjadi tujuan utama dalam pelaksanaan penyelesaian sengketa secara adat. (Pergub Nomor 60 Tahun 2013 Tentang Pelaksanaan Penyelesaian Sengketa/Perselisihan Adat Dan Istiadat Di Gampong Pasi Aceh Baroh Kecamatan Meureubo Kabupaten Aceh Barat).

Penyelesaian sengketa secara adat merupakan wadah penyelesaian sengketa yang diperankan oleh beberapa tokoh adat baik yang ada di tingkat gampong maupun di tingkat mukim. Tokoh adat yang terlibat dalam menyelesaikan sengketa inilah yang dimaksud sebagai fungsionaris penyelesaian sengketa secara adat. Tidak semua petua adat terlibat sebagai fungsionaris adat (fungsionaris penyelesaian sengketa secara adat) dalam menyelesaikan sengketa dalam masyarakat. Sekarang ini dikenal dua fungsionaris penyelesaian sengketa secara adat, yakni fungsionaris pada tingkat gampong dan fungsionaris pada tingkat mukim.

Dalam hal ini pada kasus penganiayaan yang penyelesaiannya secara adat dan istiadat di gmpong Pasi Baroh Kecamatan Meureubobelum berjalan lancar seperti Pergub Nomor60 Tahun 2013 sedikit ada masalah bukannya di selesaikan secara adat istiadat gampong, tetapi diselesaikan secara kepolisian. Padahal setidaknya jika di selesaikan dengan adat gampong tidak mengeluarkan anggaran karena hanya dengan pesijuk dan di jadikan sebagai saudara sebut. Sedangkan penyelesaian di kepolisian dapat menyebabkan dendam bagi korban. Hambatan dalam implementasi Pergub Nomor60 Tahun 2013 adalah kepercayaan masyarakat yang masih kurang terhadap pemangku dat atau pemerintah gampong, karena pengalaman sebelumnya bahwa penyelesain kasus penganiayaan tidak selesai di selesaikan dalam tingkat gampong sehingga harus ke kantor polisi.Selain itu Pemerintah Gampong Pasi Aceh Baroh yang bertindak sebagai pemangku adat belum memahami dan mengetahui sepenuhnya terkait keberadaan Pergub Nomor 60 
Community; Volume 2, Nomor 2, April 2016

ISSN; 2477-5746

Tahun 2013 Tentang Pelaksanaan Penyelesaian Sengketa/Perselisihan Adat Dan Istiadat Di Gampong Pasi Aceh Baroh Kecamatan Meureubo Kabupaten Aceh Barat

\section{KESIMPULAN}

\section{KESIMPULAN}

Peraturan Gubernur Nomor 60 Tahun 2013 Tentang Pelaksanaan Penyelesaian Sengketa/Perselisihan Adat Dan Istiadat dalam pelaksanaan di provinsi Aceh belum berjalan dengan maksimal. Begitu pula di Gampong Pasi Aceh Baroh Kecamatan Meureubo Kabupaten Aceh Barat hal tersebut dapat terlihat pada sikap masyarakat yang lebih memilih jalur hukum formal dalam penyelesaian persoalannya dari penyelesaian melalui pendekatan lembaga adat gampong khususnya di gampong Pasi Aceh Baroh Kecamatan Meureubo Kabupaten Aceh Barat. Situasi demikian dapat menunjukkan bahawa nilai kepercayaan masyarakat yang masih kurang terhadap pemangku dat atau pemerintah gampong yang semstinya harus bertanggung dalam memberikan pemahaman kepada masyarakat dalam tradisi kehidupan masyarakat yang mengutamakan mufakat dan sebagai tuntutan nilai syariat islam dalam ukhuwah islamiah. pemangku adat belum memahami dan mengetahui sepenuhnya terkait keberadaan Pergub Nomor 60 Tahun 2013 Tentang Pelaksanaan Penyelesaian Sengketa/Perselisihan Adat Dan Istiadat Di Gampong Pasi Aceh Baroh Kecamatan Meureubo Kabupaten Aceh Barat

\section{SARAN}

1. Pemerintah Kabupaten Aceh Barat memperkuat kedudukan dari segi hukum dengan peningkatan sosialisasi ke berbagai-bagai tingkat gampong. Gampong Pasi Aceh Baroh Kecamatan Meureubo Kabupaten Aceh Barat bersikap profesional dan proposional dalam menyelesaikan sengketa atau problem masyarakat dengan menjamin adanya kepastian dan keadilan hukum bagi masyarakat, sehingga keadilan itu benar-benar berpihak pada yang benar. Dengan demikian kepercayaan masyarakat terhadap pemerintahan atau pemangku adat di Gampong Pasi Aceh Baroh terbangun kembali.

2. Keuchik sebagai pemimpin eksekutif di Gampong Pasi Aceh Baroh beserta dengan jajaran Tuha Peut harus punya komitmen yang tinggi dalam menegakkan hukum, khususnya hukum adat ada karena hukum adat merupakan bagian dari hukum nasional yang diakui keberadaannya oleh negara Indonesia. Di samping itu aceh merupakan daerah yang diberikan kewenangan kekhususan untuk itu sebagaimana yang tertuang dalam Undang-undang Nomor 44 Tahun 1999 Tentang Keistimewaan Aceh.

3. Masyarakat Gampong Pasi Aceh Baroh harus memahami sepenuhnya bahwa penyelesaian sengketa secara adat ada beberapa kemudahan yang didapat seperti sebagai berikut: Pertama, Para pihak yang bersengketa tidak ada yang menang dan kalah dalam penyelesaiannya, Kedua, Penyelesaian secara adat murah dan penuh dengan unsur kekeluargaan, Ketiga, Penyelesaian secara adat mempunyai kekuatan hukum mengikat dan diakui keberadaannya oleh lembaga hukum formal, Keempat, Penyelesaian sengketa secara adat cepat dan tepat 
penyelesaiannya dan merupakan nilai kekuatan dari adat istiadat Aceh dalam perspektif syariat islam di Aceh.

\section{REFERENSI}

Abdullah, Adnan. 1982. Kepemimpinan Pedesaan di Aceh. Banda Aceh: Universitas Syiah Kuala

Djuned, T. M. 2003. Menuju Revitalisasi Hukum dan adat Aceh, Yayasan Rumpun Bambu dan CSSP, Jakarta

Denzim, Norman K. 2009. Hamdbook Qualitative Reasearch, Jakarta: Pustaka Pelajar

Miles Mattthew B. And Michel Hebertmen. 1992, Analisa Data Qualitatif buku sumber tentang metode-metode baru. Jakarta. UI. Press

Pedoman Peradilan Adat di Aceh di Aceh "Untuk Peradilan Adat yang Adil dan Akuntabel". 2016. Majelis Adat Aceh

Sulaiman Tripa, Prospek dan Tantangan Pemerintahan Gampong di Nanggoroe Aceh Darussalam, Jurnal Media Hukum, Vol 16 No 2 Desember 2009.

\section{Sumber Hukum:}

Undang-Undang Nomor 44 Tahun 1999 Tentang Keistimewaan Aceh

Peraturan Gubernur Nomor 60 Tahun 2013 Tentang Pelaksanaan Penyelesaian Sengketa/ Perselisihan Adat Dan Istiadat dalam pelaksanaan di provinsi Aceh

Undang - Undang Nomor 11 Tahun 2006 Tentang Pemerintahan Aceh.

Qanun Aceh Nomor 5 Tahun 2003 Tentang Pemerintahan Gampong

Qanun Aceh Nomor 7 Tahun 2008 Tentang Adat Istiadat

Peraturan Gubernur Nomor 60 Tahun 2013 Tentang Pelaksanaan Penyelesaian Sengketa/Perselisihan Adat Dan Istiadat 